\title{
Гранулометрический состав донных отложений озера Торосъярви (бассейн Белого моря)
}

\author{
Н.А. Мясникова ${ }^{凶}$, М.С. Потахин \\ Федеральный исследовательский центр «Карельский научный центр Российской академии наук» \\ Института водных проблем Севера КарНЦ РАН, Российская Федерация \\ (185030, г. Петрозаводск, пр. Александра Невского, 50)
}

\begin{abstract}
Аннотация: Цель - исследовать донные отложения малого реликтового озера Торосъярви для реконструкции развития и уточнения границы Онежского приледникового озера в позднеледниковье и голоцене.

Memoды. Определение гранулометрического состава донных отложений выполнено на лазерном многофункциональном анализаторе частиц LS 13320 (фирмы Beckman Coulter, США) в Центре коллективного пользования КарНЦ РАН с последующей статистической обработкой данных.

Результаты. В ходе экспедиционных работ вскрыты два разреза донных осадков, дано их полевое литостратиграфическое описание. В лабораторных условиях выполнен анализ гранулометрического состава донных отложений на участке 4,40-5,40 м (керн 2,5). Установлено, что размеры фракций изменяются от мелких песков до тонких глин. Донные отложения представлены, главным образом, фракцией крупного ила. Палеогидродинамические обстановки осадконакопления пород по данным гранулометрического анализа характеризуют три интервала 4,68 4,69; 5,04-5,05 м и 5,14-5,15 м как турбидитные отложения, остальные интервалы 4,71-4,81 м и 5,24-5,35 м попадают в зону отложения течений с низкими скоростями (однородные осадки взвеси).

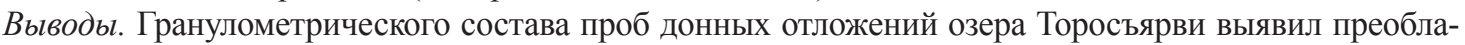
дание в них фракции крупного ила, содержание которой колеблется от 49,04 \% до 62,96 \%. Содержание песчаной фракции $-21,36-38,62 \%$ и представлено в основном тонкозернистой фракцией. Глинистая фракция - 0,44-1,61 \%. Первичный анализ динамики осадконакопления оз. Торосьярви по керну донных отложений в интервале 4,4-5,4 м предполагает пять смен динамических режимов вод в процессе его формирования. Результаты работы необходимы для дальнейших геоэкологических и палеогеографических исследований.
\end{abstract}

Ключевые слова: донные отложения, гранулометрический состав, фракции, Карелия.

Источник финансирования: Финансовое обеспечение исследований осуществлялось из средств федерального бюджета на выполнение государственного задания КарНЦ РАН (Институт водных проблем Севера КарНЦ РАН).

Для цитирования: Мясникова Н. А., Потахин М.С. Гранулометрический состав донных отложений озера Торосъярви (бассейн Белого моря) // Вестник Воронежского государственного университета. Серия: География. Геоэкология, 2021, № 1, с. 45-56. DOI: https://doi.org/10.17308/geo.2021.1/3255

\section{ВВЕДЕНИЕ}

Важным моментом исследования озер, и в первую очередь их донных отложений, является детальное изучение природно-климатических условий прошлого, без которого невозможно понимание современных климатических изменений и их правильная оценка. Одним из способов изучения палеоклиматической и палеогеографической изменчивости является комплексный анализ донных осадков озер. Отложения, накапливаемые на дне водоемов, выступают важнейшим компонентом водных экосистем, являясь продуктом седиментации органического и неорганического материала. На процесс их формирования оказывают влия-

(C) Н. А. Мясникова, М.С. Потахин, 2021

$\triangle$ Мясникова Надежда Александровна, e-mail: nadezda_myasnikova@mail.ru

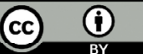
Контент доступен под лицензией Creative Commons Attribution 4.0 License. 
ние такие факторы как климатические условия, растительный покров, гидрологический режима объекта, антропогенная деятельность. Изменение гранулометрического состава отложений по колонке донных отложений характеризует изменение гидрологического режима и уровня воды в прошлом [9]. Данные, полученные при комплексном изучении колонок, дают необходимые сведения для геомониторинга. Зачастую палеолимнологические исследования являются безальтернативным источником информации об изменениях водоемов в прошлом, в том числе, внешних воздействиях на водные объекты. Кроме детальной геохронологии внешнего наземного и атмосферного воздействия, донные отложения позволяют получить биологическую запись отклика озерной экосистемы на природно-климатические изменения.

В рамках изучения развития Онежского озера в позднеледниковье и голоцене Институтом водных проблем Севера проводятся исследования донных отложений малых реликтовых озер Прионежья [8; 12; 14]. Результаты работ обобщаются в базе данных PaleoOnego [10] и используются для выполнения реконструкций развития водоема $[11,18]$. Следует отметить, что в аллёрде (около 13,3 тыс. л.н.), в максимальную стадию своего развития, Онежское приледниковое озеро (ОПО) в несколько раз превышало размеры современного водоема [2]. Его границы выходили далеко на север за пределы настоящего водосбора и включали озерные котловины Сегозера и Выгозера (в пределах абсолютных высот от 140 м на западе до 115 м на востоке). Именно поэтому изучение малых реликтовых озер в краевых зонах развития ОПО весьма актуально, так как позволяет уточнить границы развития приледникового водоема.

\section{ОБЪЕКТ И МЕТОДЫ ИССЛЕДОВАНИЯ}

Объект исследования - озеро Торосъярви, расположенное в административных границах Медвежьегорского района Республики Карелия. В гидрологическом плане водоем относится к бассейну Белого моря (верхняя часть водосбора р. Выг (Беломорско-Балтийский канал)). Координаты географического центра озера: 6329' с.ш., 33ำ $14^{\prime}$ в.д. Высота над уровнем моря 120,4 м (Балтийская система отсчета). Из озера вытекает ручей без названия, соединяющий его с оз. Сяргозером, оз. Сонозером и р. Воломой. Водоем имеет неправильную вытянутую форму, ориентирован в северо-северо-западном направлении. Длина озера 1,7 км, максимальная ширина - 0,7 км, площадь - 0,580 км² (рис. 1a), глубина достигает 7,5 м.
В орографическом плане район оз. Торосъярви относится к восточной части Западно-Карельской возвышенности, к зоне сочленения ее центральной и восточной цепей гряд. Рельеф района характеризуется как денудационно-тектонический, средний и мелкий грядово-холмистый $[1,7]$. В ходе материковых оледенений четвертичного периода поверхность коренных кристаллических пород подвергалась значительным преобразованиям. Особенно ярко здесь проявляются следы деятельности последнего валдайского оледенения (территория находится между краевыми моренами невской и ругозерской (сальпаусселькя I) стадий). Помимо выходов коренных дочетвертичных пород, здесь повсеместно распространены различные формы ледникового аккумулятивного рельефа, представленные ледниковыми, водно-ледниковыми, озерно-ледниковыми четвертичными отложениями.

Непосредственно о3. Торосъярви находится в зоне распространения песчано-гравийных отложений вне озов, в пределах развития озерно-ледниковой равнины [17].

В проведенных нами реконструкциях [11, 18] район озера Торосъярви расположен в северной части ОПО в период его максимального развития (рис. 1б). Это подтверждают и морфологические следы приледникового озера, существовавшего в котловине современного Сегозера и к северо-западу от него (оз. Сонозеро, оз. Маслозеро, оз. Лазоревское, оз. Торосъярви и др.), выраженные в виде обширной озерной равнины с мелкими озерами-реликтами, а также террасами берегов современных озер.

Летом 2015 года нами было выполнено морфологическое обследование котловины озера и батиметрическая съемка. Отбор колонки донных отложений проводился весной 2016 года со льда с применением штангового торфяного бура. В ходе полевых работ вскрыты скважины в двух точках (рис. 1a): точка 1 (керн 1,1), точка 2 (керны 2,12,5). На месте выполнено краткое литостратиграфическое описание кернов донных отложений (таблица). Полученные образцы были герметично упакованы, доставлены в институт и помещены в депозитарий для их дальнейшего изучения.

Для определения механического состава донных отложений выбран лазерный метод, отличающийся от классических методов гранулометрического анализа (ситовой, ареометрический, пипеточный и др.) меньшей трудоемкостью, большей точностью и скоростью получения результатов $[3,13]$. Разделение проб по фракциям осущест- 


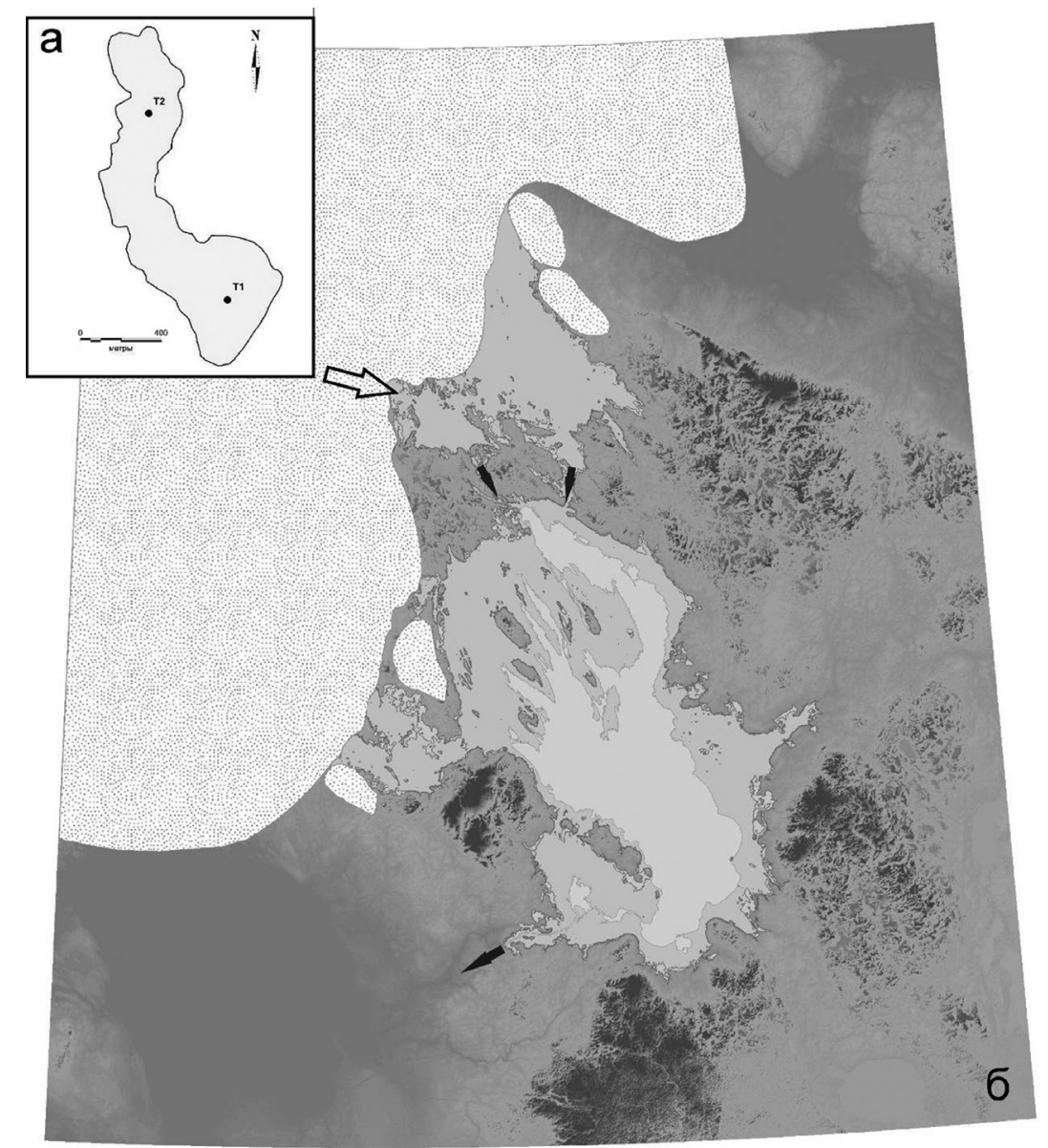

Рuc.1. Географическое положение объекта исследования:

а - озеро Торосъярви Т1, Т2 - точки отбора проб для исследования;

б - максимальная стадия развития ОПО (около 13,3 тыс. л.н.) (черная стрелка - направление стока) [11]

[Fig. 1. Geographical location of the study object: a - Torosjarvi Lake T1, T2 - sampling points;

6 - Periglacial lake Onego at its maximum (ca. 13,3 Ka B.P.) (black arrow marks drainage direction) [11]]

влялось на лазерном многофункциональном анализаторе частиц LS 13320 (фирмы Beckman Coulter, США) в Центре коллективного пользования КарНЦ РАН.

Метод квартилей, представленный П. Траском [16] - один из главных способов количественной оценки статистик практических распространений частиц по размерам. В данном случае общее число гранулометрических фракций описывают тремя значениям: $\mathrm{M}_{\mathrm{d}}$ - медиана, $\mathrm{Q}_{1}$ - первая и $\mathrm{Q}_{3}$ - третья квартиль. Через ординаты строят горизонтальные линии, соответствующие 25, 50, 75 \%, пока они не пересекутся с кумулятивной кривой. Абсциссы полученных точек пересечения представляют начальные данные для вычисления гранулометрических коэффициентов.Для определения механического состава донных отложений выбран лазерный метод, отличающийся от классических методов гранулометрического анализа (ситовой, ареометрический, пипеточ- ный и др.) меньшей трудоемкостью, большей точностью и скоростью получения результатов $[3,13]$. Разделение проб по фракциям осуществлялось на лазерном многофункциональном анализаторе частиц LS 13320 (фирмы Beckman Coulter, США) в Центре коллективного пользования КарНЦ РАН.

Методквартилей, представленныйП. Траском [16] - один из главных способов количественной оценки статистик практических распространений частиц по размерам. В данном случае общее число гранулометрических фракций описывают тремя значениям: $\mathrm{M}_{\mathrm{d}}$ - медиана, $\mathrm{Q}_{1}$ - первая и $\mathrm{Q}_{3}$ - третья квартиль. Через ординаты строят горизонтальные линии, соответствующие 25, 50, 75 \%, пока они не пересекутся с кумулятивной кривой. Абсциссы полученных точек пересечения представляют начальные данные для вычисления гранулометрических коэффициентов. 
Описание кернов донных отложений оз. Торосъярви

[Table. Description of bottom sediment cores from the Torosjarvi Lake]

\begin{tabular}{|c|c|}
\hline $\begin{array}{l}\text { Шифр керна (мощность) / } \\
\text { Core code (size) }\end{array}$ & $\begin{array}{c}\text { Полевое описание керна / } \\
\text { Core description from the field }\end{array}$ \\
\hline $\begin{array}{l}\text { Керн } 1,1 / \text { core } 1,1 \\
(4,40-5,40 \mathrm{~m})\end{array}$ & $\begin{array}{l}\text { 4,40-4,75 м - сапропель с песком } \\
\text { 4,75-5,29 м - серая глина } \\
\text { 5,29-5,40 м - рыхлый мелкозернистый песок }\end{array}$ \\
\hline $\begin{array}{l}\text { Керн } 2,1 / \text { core } 2,1 \\
\quad(4,50-5,50 \mathrm{~m})\end{array}$ & $\begin{array}{l}\text { 4,5-5,5 м серые глины с черными прослойками (варвы?) } \\
4,69 \text { м - включения органики (водоросли?) } \\
\text { 4,72 м - включения органики }\end{array}$ \\
\hline $\begin{array}{l}\text { Керн } 2,2 \text { / core } 2,2 \\
\quad(3,00-4,00 \mathrm{~m})\end{array}$ & $\begin{array}{l}\text { 3,00-3,23 м - темный сапропель } \\
\text { 3,23-3,29 м - светлый (оливковый) сапропель } \\
\text { 3,29-3,39 м - более темный сапропель } \\
\text { 3,39-3,45 м - светлый сапропель } \\
\text { 3,45-4,00 м - темный сапропель }\end{array}$ \\
\hline $\begin{array}{l}\text { Керн } 2,3 \text { / core } 2,3 \\
\quad(3,8-4,8 \text { м })\end{array}$ & $\begin{array}{l}3,8-4,06 \text { м - темный сапропель } \\
4,06-4,18 \text { м - переход от сапропеля к глинам } \\
4,18-4,47 \text { м - глина гомогенная } \\
4,47-4,80 \text { м - ленточные глины (4,68 м; 4,69 м включения органики } \\
\text { (водоросли?)) }\end{array}$ \\
\hline $\begin{array}{c}\text { Керн } 2,4 / \text { core } 2,4 \\
(2,5-3,5 \mathrm{~m})\end{array}$ & $\begin{array}{l}2,50-3,20 \text { м - сапропель } \\
3,20-3,50 \text { м - переход к оливковому сапропелю }\end{array}$ \\
\hline $\begin{array}{l}\text { Керн } 2,5 \text { / core } 2,5 \\
(4,4-5,4 \text { м })\end{array}$ & $\begin{array}{l}\text { Расширенное описание с использованием определителя [16] } \\
\text { 4,4-4,69 м - глинистый алеврит оливкового цвета (цветность по шкале } \\
[16]) \text { от 5Y 4/3 до 5Y 4/2) } \\
4,46-4,47 \text { м - глинистый прослой (5Y 5/1) } \\
\text { 4,62-4,69 м - увеличение содержания органики } \\
\text { C 4,70 м - сортированные, хорошо окатанные пески с обильным } \\
\text { содержанием кварца, по цветовому определителю градация оттенка } \\
\text { колеблется от 5Y 6/1 до 5Y 7/1 }\end{array}$ \\
\hline
\end{tabular}

Для оценки гранулометрического спектра методом квартилей использовались коэффициенты $\mathrm{M}_{\mathrm{d}}, \mathrm{S}_{0}$ и $\mathrm{S}_{\mathrm{k}}\left(\mathrm{M}_{\mathrm{d}}\right.$ - медиана, показывает среднюю величину зерен; $\mathrm{S}_{0}-$ коэффициент сортировки, $\mathrm{S}_{\mathrm{k}}$ - коэффициент асимметрии). Коэффициент сортировки определяется по уравнению (1):

$$
S_{0}=\sqrt{Q_{3} / Q_{1}}
$$

Коэффициент сортировки $\mathrm{S}_{0}$ показывает уровень однообразия частиц данной совокупности. Значение $\mathrm{S}_{0}$ может меняться в широком диапазоне от первых единиц до первых десятков.

Коэффициент асимметрии определяется по равенству (2):

$$
S_{\mathrm{k}}=Q_{1} Q_{3} / M_{d}^{2}
$$

Коэффициент асимметрии $\mathrm{S}_{\mathrm{k}}$ указывает, в какую сторону меньших или больших величин смещен диаметр наиболее распространенных частиц (мода) относительно вычисленного медианного диаметра.
По кумулятивной кривой можно определить коэффициент крупности К, характеризующий крупнозернистую часть породы. Эта величина устанавливает размерность зерен, относительно которой более крупные зерна, встречаемые в породе, составляют $1 \%$ от всей породы. Крупнозернистая часть породы соответствует максимальной силе потока.

\section{РЕЗУЛЬТАТЫ И ОБСУЖДЕНИЕ}

Более детально был изучен керн донных отложений с глубины 4,4-5,4 м (керн 2,5, отобранный во второй точке). Последовательность типов осадочных пород (глина-алеврит-песок) в изученной части керна озеро Торосьярви обладает характерными чертами.

В ходе исследования было выявлено, что количество зерен кварца увеличивается вверх по разрезу. С глубиной сначала происходит уменьшение алевритовой фракции за счет увеличения фракции песка и появления фракции глины (переход от интервала 4,68-4,69 м к 4,71-4,72 м). В интервалах представлены скопления растительных остатков (рис. 2a). 

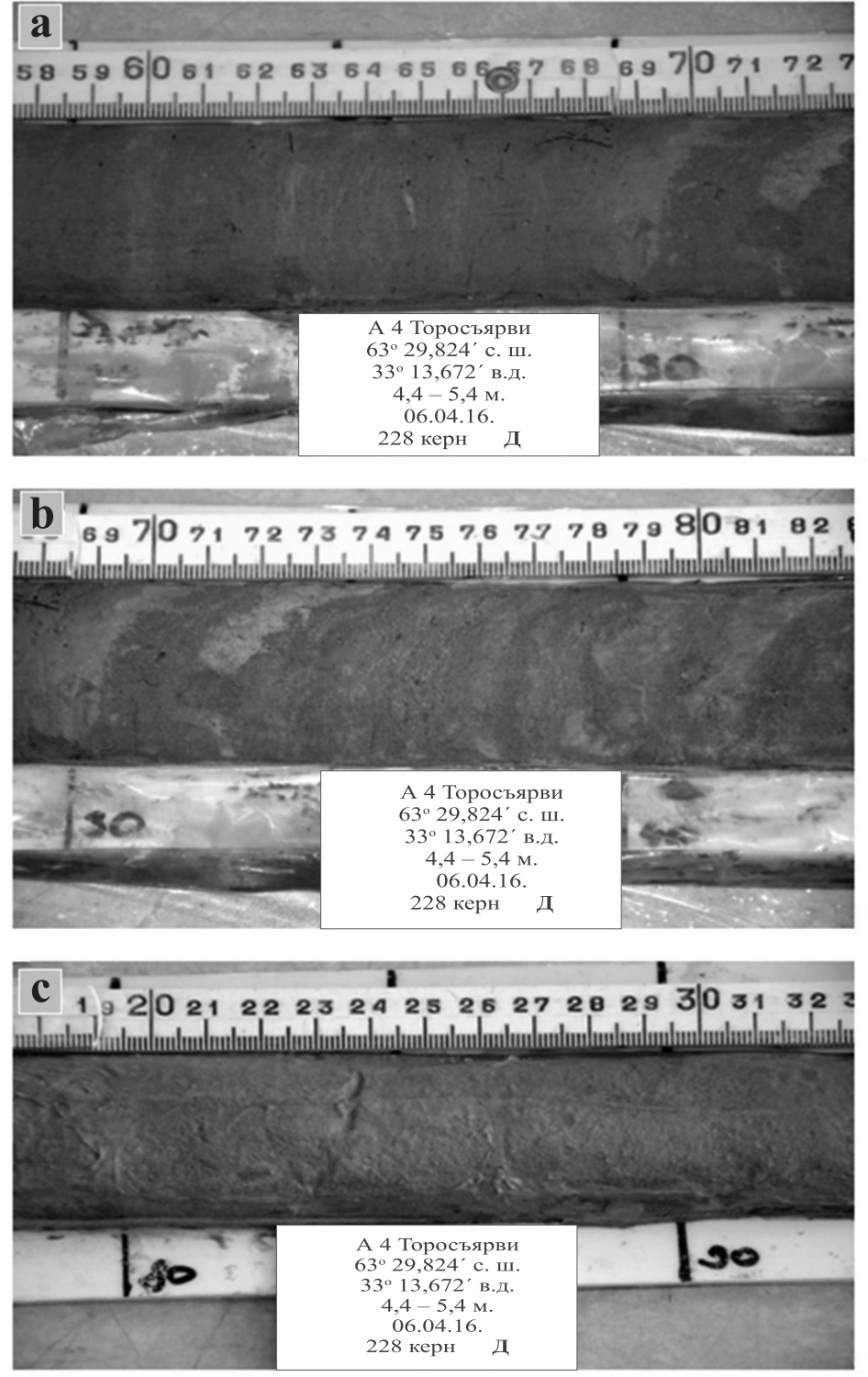

Рuс. 2. Керн донных отложений оз. Торосъярви:

a - скопление остатков растительности в слое 4,62-4,69 м; b - неравномерная косая слоистость; c - средне отсортированные глинистые алевриты в слое 5,20-5,25 м

[Fig. 2. Sediment core from the Torosjarvi Lake:

$\mathrm{a}$ - aggregation of plant residues in the 4,62-4,69 m layer; $\mathrm{b}$ - uneven cross-bedding; $\mathrm{c}$ - moderately sorted clayey silt 5,20-5,25 m layer]

Далее следует увеличение алевритовой фракции с одновременным исчезновением фракции глины и уменьшением песчаной фракции (переход от интервала 4,74-4,75 к 4,76-4,77). В интервале 4,68-4,82 м наблюдается косая слоистость с неравномерно волнистым напластовыванием, которая, вероятно, является результатом транспортировки обломочного материала перекатыванием, волочением по русловому ложу и его осаждения в форме серповидных «дюн» (рис. 2b).

С глубины 4,8 м наблюдается увеличение алеврита с появлением фракции глин и песка. Например, содержание алевритовой фракции в слое
4,8-4,81 м составляет 88,2 \%, фракции песка $9,0 \%$, фракции глины $-2,8 \%$. В слое 5,045,05 м алевритовая фракция равна 91,3\%, фракция песка $-8,8 \%$, в слое 5,14-5,15 м алевритовая фракция - 91,5\%, фракция песка $-8,5 \%$, а в слое 5,24-5,25 м алевритовая фракция - 90,4 \%, фракция песка $-8,7 \%$, фракция глины - 1,0 \%.

Гранулометрический анализ донных отложений оз. Торосъярви был выполнен для десяти проб с глубины 4,68-5,35 метра. Классификация фракций донных отложений по размерам частиц выполнена по В.Д. Ломтадзе [6]. Гранулометрический анализ донных отложения оз. Торосьяр- 
ви показал преобладание фракции крупных илов (0,01-0,05 мм), составляющей от $49 \%$ до $63 \%$. Фракция песка представлена мелкими песками $(0,1-$ 0,25 мм) от $5 \%$ до $12 \%$ и тонкими песками $(0,05$ 0,1 мм) от $21 \%$ до $39 \%$. Фракция глины встречается не во всех интервалах отбора и составляет около $1 \%$.
Графическое представление гранулометрического состава исследованных проб изображено на диаграммах кривых распределения размерных фракций на рисунке 3a и 3b. Группировка фракций выполнена для лучшего представления общих закономерностей и выявления различий в графическом виде.

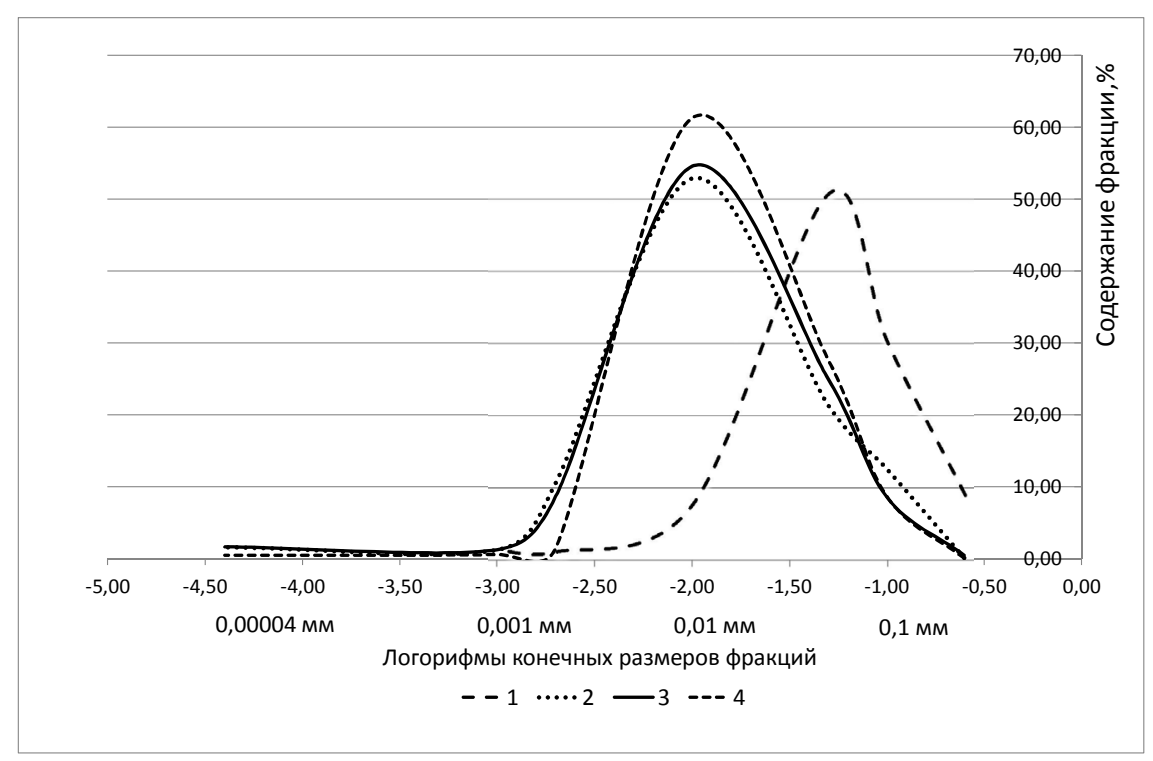

a

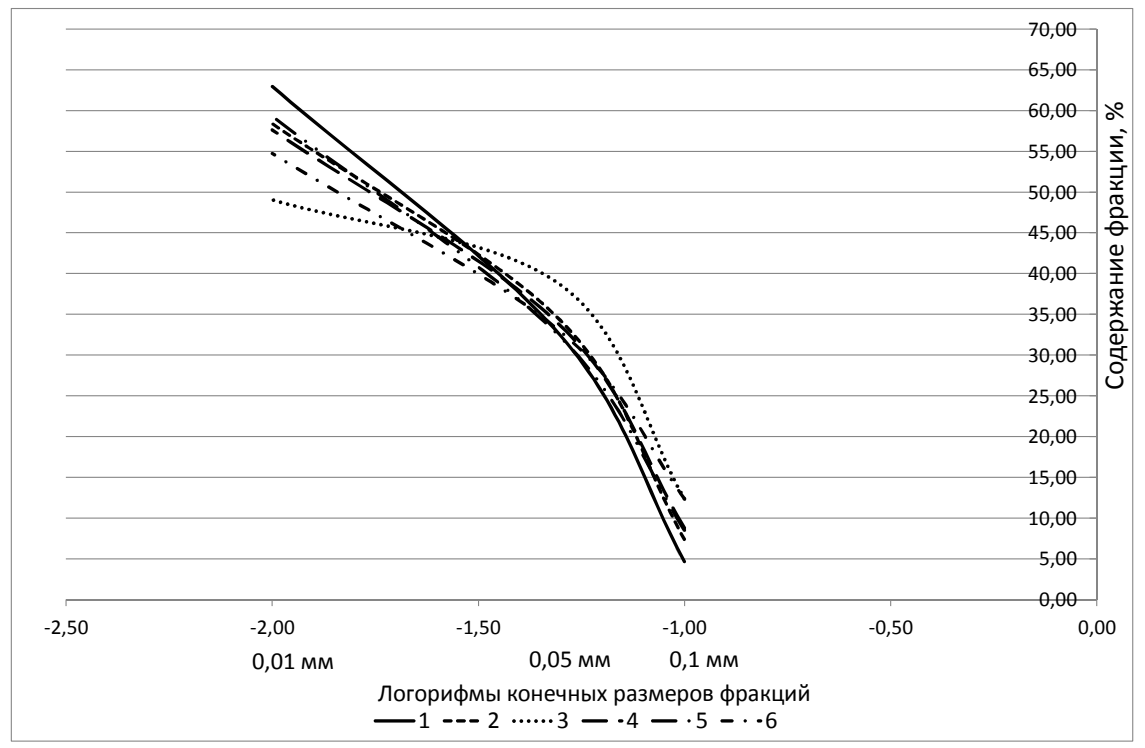

b

Puc. 3. Диаграмма кривых распределения размерных фракций донных отложений:

[Fig. 3. Diagram of the distribution curves of the size fractions of bottom sediments:]

a - интервал отбора, м

[a - sampling interval, $\mathrm{m}$ ]

1. $4,71-4,72$

2. $4,74-4,75$

3. $4,8-4,81$

4. $5,24-5,25$ b - интервал отбора, м

[b - sampling interval, $\mathrm{m}$ ]
1. $4,68-4,69$
2. $4,76-4,77$
3. $4,78-4,79$
4. 5,04-5,05
5. $5,14-5,15$
6. 5,34-5,35 
Для расчета коэффициента сортировки $\left(\mathrm{S}_{\circ}\right)$, коэффициента асимметрии $\left(\mathrm{S}_{\mathrm{k}}\right)$ и коэффициента крупности (К), были построены кумулятивные кривые (рис. 4).

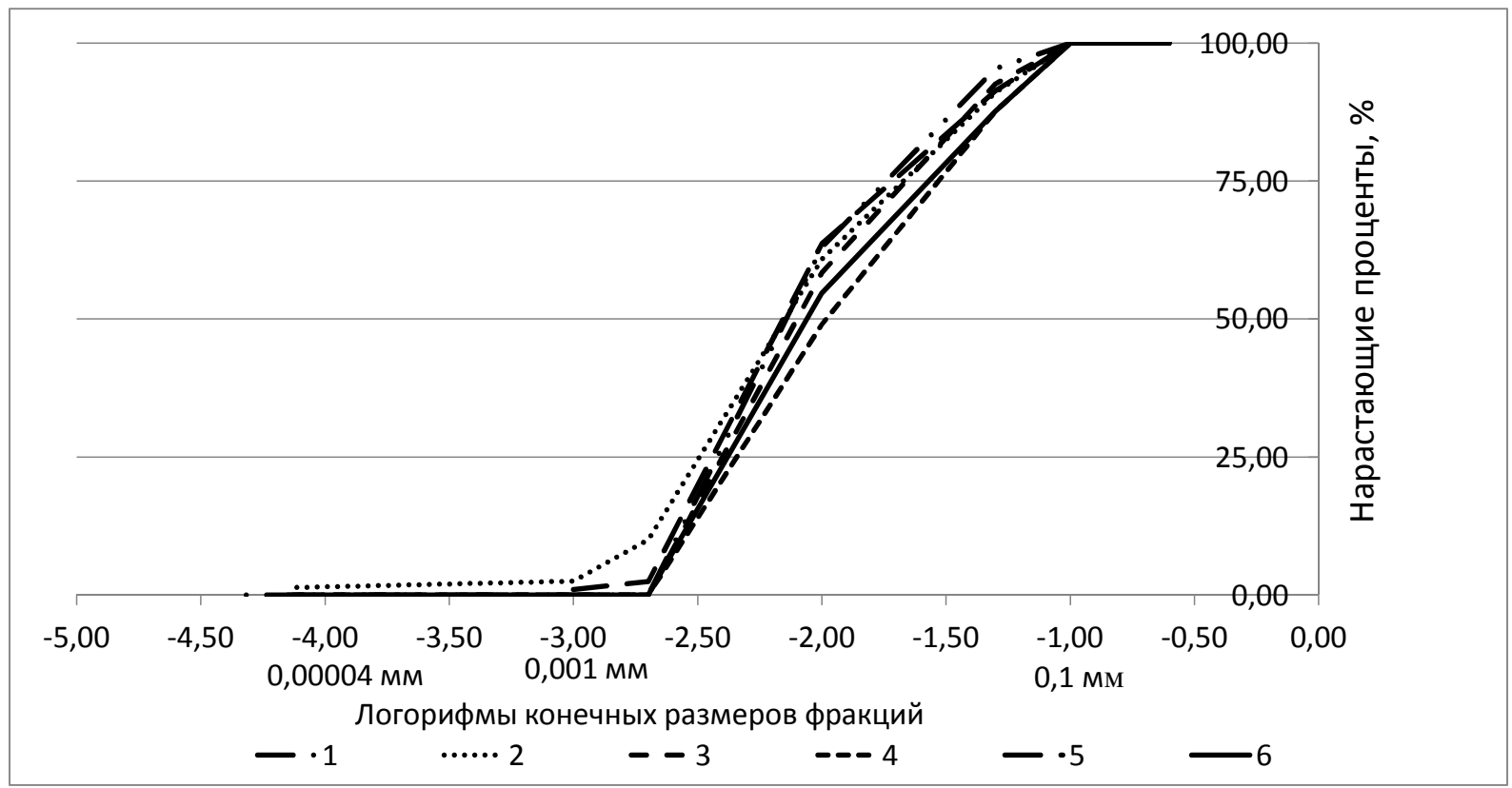

Pис. 4. Диаграмма кумулятивных кривых образцов проб донных отложений оз. Торосъярви, интервал отбора, м:

[Fig. 4. Diagram of the cumulative curves for sediment samples from the Torosjarvi Lake, sampling interval, m:] 1. 4,68-4,69; 2. 4,71-4,72; 3. 4,76-4,77; 4. 4,78-4,79; 5. 5,24-5,25; 6. 5,34-5,35

Построение кумулятивных кривых и нахождение коэффициентов выполнено с использованием методики С. А. Коваля и Г. В. Войцеховского [5]. Полученные результаты представлены на рисунке 5.

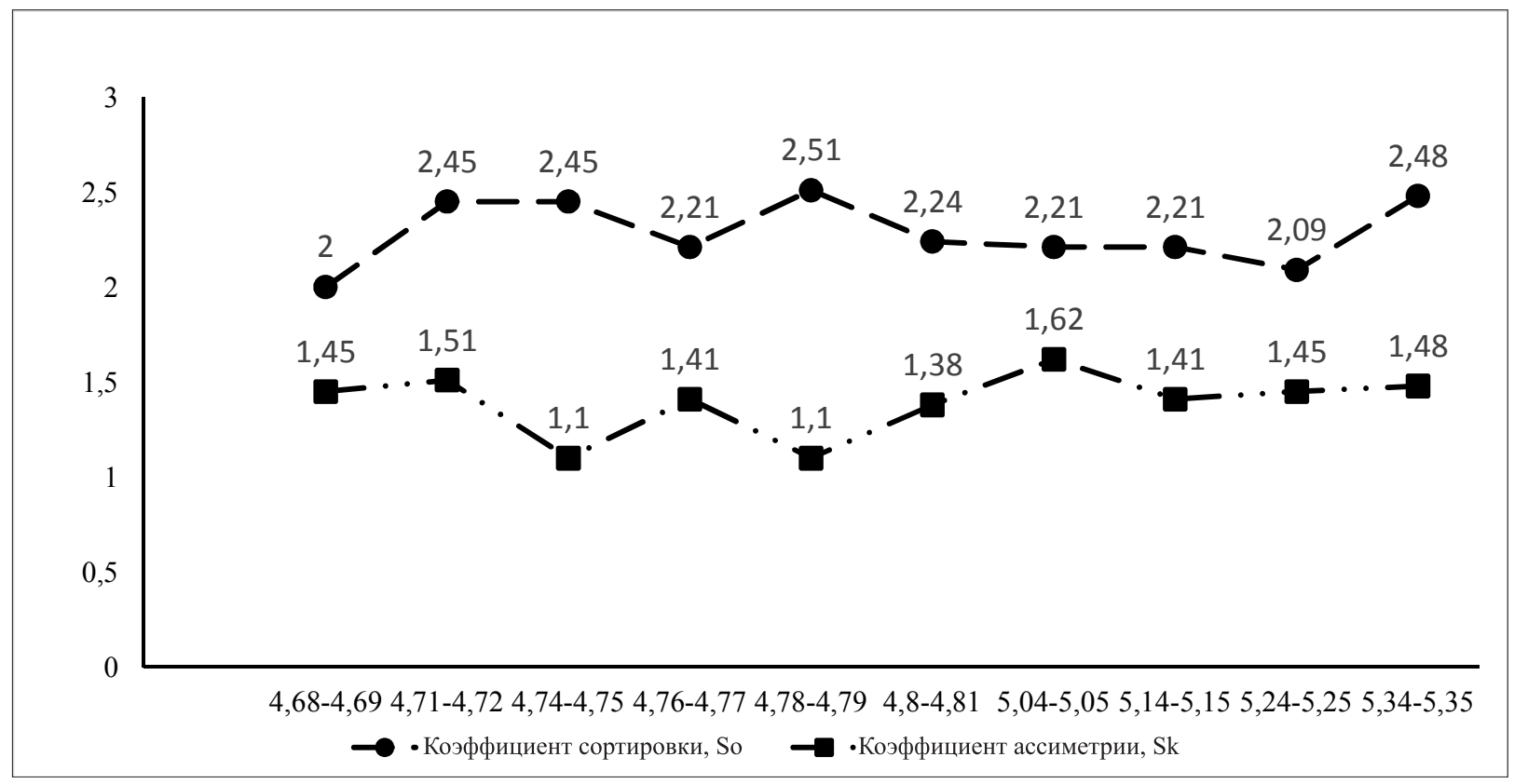

Puc. 5. Динамика коэффициента сортировки и коэффициента асимметрии для поверхностных проб донных отложений оз. Торосъярви

[Fig.5. Dynamics of the coefficient of sorting and coefficient of skewness in top-core sediments from the Torosjarvi Lake] 
Все осадки по степени сортировки, согласно классификации П. Траска, можно подразделить на хорошо отсортированные $\left(\mathrm{S}_{0}=1,0-1,58\right)$, средне сортированные $\left(\mathrm{S}_{0}=1,58-2,12\right)$ и плохо сортированные $\left(\mathrm{S}_{0}>2,12\right)$.

Донные отложения изученного участка керна (с глубины 4,4-5,4 м) являются, в основном, плохо сортированными осадками (коэффициент сортировки $\mathrm{S}_{0}$ изменяется от 2,21 до 2,51). Пробы донных отложений интервала 4,68-4,69 м $\left(\mathrm{S}_{0}=2,0\right)$ и $5,24-5,25$ м $\left(\mathrm{S}_{0}=2,09\right)$ относятся к средне сортированным осадкам (рис. 5). В интервале 5,20-5,25 м визуально выделяется цветовая последовательность слоев в тонкозернистых, средне отсортированных глинистых алевритах от серых до оливково-серых (от 5Y 4/3 до 5Y 4/2) (рис. 2c). Вероятно, они сформировались в результате латерального наращивания осадочного материала на отмели. Пробы интервала 4,71-5,15 м и 5,34-5,35 м плохо сортированные осадки $\left(\mathrm{S}_{0}\right.$ изменяется от 2,21 до 2,51).
Если значение коэффициента асимметрии больше единицы, то в осадке преобладает мелкая фракция, при коэффициенте асимметрии меньше единицы, преобладающей будет крупная фракция [4]. Коэффициент асимметрии для всех исследованных интервалов имеет положительное значение и колеблется от 1,1 до 1,62 , а большая часть значений лежит в пределах 1,38-1,51. Следовательно, большая часть донных отложений тяготеет к преобладанию мелкой фракции, в частности к крупным илам, размер фракции 0,01-0,05 мм.

Анализ палеогидродинамической обстановки осадконакопления пород выполнен с использованием генетической диаграммы Р. Пассега [15], учитывающей способ переноса кластического материала путем качения частиц, сальтацией, транспортировкой в виде суспензии. Транспортировка крупно- и тонкозернистых фракций происходит независимо. Для построения диаграммы используются два значения: медианный диаметр и крупнозернистая часть породы (К) (рис. 6).

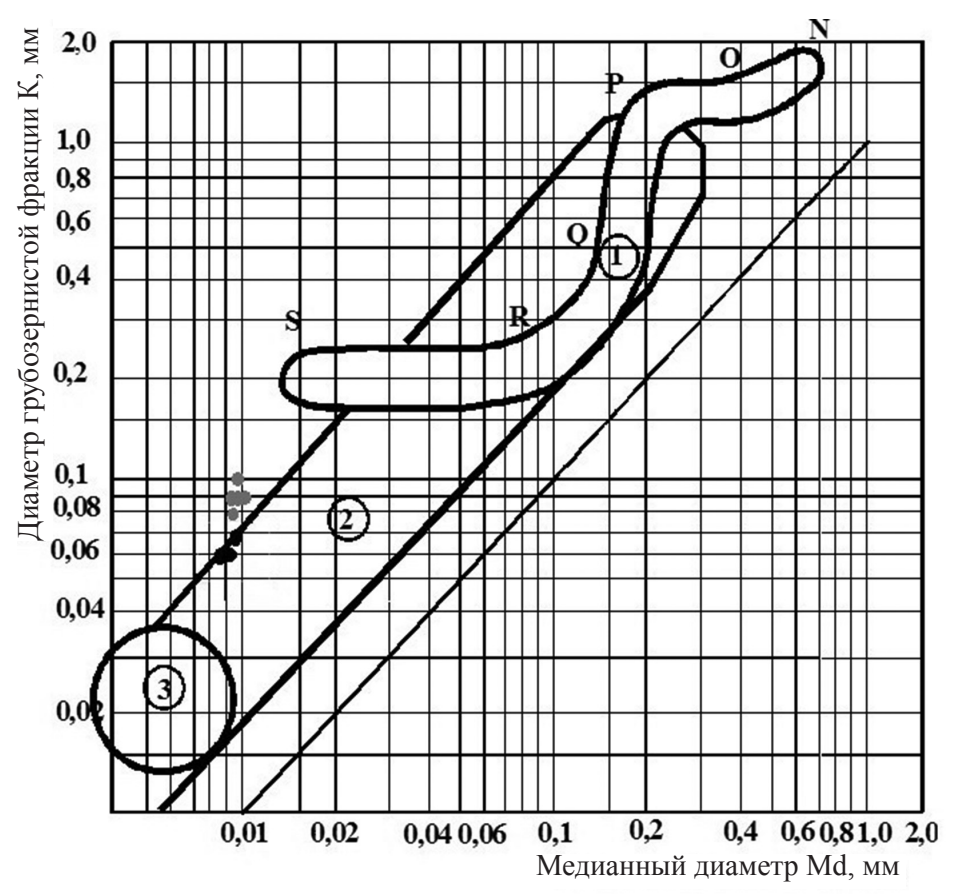

Рuc. 6. Распределение точек-проб озера Торосъярви на генетической диаграмме Р. Пассеги

N/O - осадки перекатывания; О/P - осадки перекатывания с незначительным количеством осадков взвеси; $\mathrm{P} / \mathrm{Q}$ - осадки взвеси с некоторым количеством осадков перекатывания (отложения течений с высокими скоростями);

$\mathrm{Q} / \mathrm{R}$ - отложения течений со средними скоростями;

$\mathrm{R} / \mathrm{S}$ - однородные осадки взвеси (отложения течений с низкими скоростями).

1.Отложения потоков; 2. Турбидитные отложения; 3. Осадки, отложенные из взвеси в спокойных водах

[Fig. 6. Distribution of sampling points in the Torosjarvi Lake over the Passega genetic diagram

$\mathrm{N} / \mathrm{O}$ - rolling sediments; $\mathrm{O} / \mathrm{P}$ - rolling sediments with minor amounts of suspension sediments;

$\mathrm{P} / \mathrm{Q}$ - suspension sediments with some rolled sediments (deposited by high-velocity streams); $\mathrm{Q} / \mathrm{R}$ - sediments deposited by moderate-velocity streams;

$\mathrm{R} / \mathrm{S}$ - uniform suspension sediments (deposited by low-velocity streams).

1. Stream sediments; 2. Turbidite deposits; 3. Sediment deposited from suspension in quiet waters] 
Три интервала 4,68-4,69 м; 5,04-5,05 м и 5,14-5,15 м попали в зону турбидитных отложений, остальные интервалы 4,71-4,81 м и 5,24-5,35 м - однородные осадки взвеси (отложения течений с низкими скоростями).

\section{ВЫВОДЫ}

Выполнение работ по мониторингу водных объектов приводит к значительному накоплению данных, позволяющих оценить и охарактеризовать состояние водоема и возможность предсказать его дальнейшее развитие.

Морфологические исследования оз. Торосъяри позволило сделать предположение о реликтовом происхождении водоема - котловины остаточного типа, согласно генетической классификации озер Карелии. Это подтверждают относительно небольшие размеры и простая форма котловины, относительно слабоизвилистая береговая линия, невысокие берега, ровное и пологое чашеобразное дно, небольшие глубины.

Отбор донных отложений и их полевое описание выявили, что органические сапропели мощностью около 1,5 м подстилаются слоем гомогенных и ленточных глин.

Проведенные лабораторные исследования, в частности изучение гранулометрического состава проб донных отложений оз. Торосъярви, выявили преобладание в них крупноалевритовой фракции, содержание которой колеблется от 49,04 \% до $62,96 \%$. Доля песчаной фракции - 21,36-38,62 \% и представлено в основном тонкозернистой фракцией. Глинистая фракция - 0,44-1,61 \%.

Вычисленные на основе графиков кумулятивных кривых коэффициенты сортировки осадочного материала показали низкий уровень сортировки донных отложений в большинстве исследуемых образцов.

Из анализа расположения точек на диаграмме Р. Пассеги следует, что три интервала (4,68-4,69 м; $5,04-5,05$ м и 5,14-5,15 м) попадают в зону турбидитные отложения, остальные интервалы являются однородными осадками взвеси - отложения течений с низкими скоростями.

Первичный анализ динамики осадконакопления оз. Торосъярви по керну донных отложений в интервале 4,4-5,4 м предполагает пять смен динамических режимов вод в процессе его формирования.

Выполненные исследования донных отложений дают информацию не только об осадконакоплении в малых озерах бассейна Белого моря, но и позволяют уточнить границы развития Онежского приледникового водоема.

\section{СПИСОК ЛИТЕРАТУРЫ}

1. Демидов И.Н. Четвертичные отложения // Разнообразие биоты Карелии: условия формирования, сообщества, виды, 2003, с. 19-27.

2. Демидов И.Н. О максимальной стадии развития Онежского приледникового озера, изменении его уровня и гляциоизостатическом поднятии побережий в позднеледниковье // Геология и полезные ископаемые Карелии, 2006, вып. 9, с. 171-182.

3. Здобин Д.Ю., Семенова Л.К. О гранулометрическом анализе глинистых грунтов: лазерные и классические методы // Геоэкология, инженерная геология, гидрогеология, геокриология, 2011, № 6, с. 560-567.

4. Ежова А.В. Практикум по литологии: учебное пособие. Томск: Изд-во ТПУ, 2011. 147 с.

5. Коваль С. А., Войцеховский Г.В. Компьютерная обработка результатов гранулометрического анализа и их генетическая интерпретация. Воронеж: Изд-во ВГУ, $2001.35 \mathrm{c.}$

6. Ломатидзе В.Д. Инженерная геология. Инженерная петрология - 2-е изд., перераб. и доп. Ленинград: Недра, 1984. 511 с.

7. Лукашов А.Д. Геоморфологические условия // Разнообразие биоты Карелии: условия формирования, сообщества, виды, 2003, с. 13-19.

8. Потахин М. С. Рязанцев П. А., Гурбич В. А., Родионов А. И., Субетто Д. А. Изучение озерных отложений юго-западного Прионежья // Материаль научно-практической конференции «Геоэкологические проблемы и устойчивое развитие Балтийского региона», Великий Новгород, 2017, с. 55-61.

9. Субетто Д.А., Прыткова М.Я. Донные отложения разнотипных водоемов. Методы изучения. Петрозаводск: Карельский научный центр РАН, 2016. 89 с.

10. Субетто Д.А., Потахин М.С., Шелехова Т.С., Гурбич В. А. Палеогеография Онежского озера и его водосбора «PaleoOnego». Свидетельство о государственной регистрации базы данных № 2017620010. 2017.

11. Субетто Д. А., Потахин М.С., Зобков М.Б., Тарасов А. Ю., Шелехова Т. С., Гурбич В. А. Развитие Онежского озера в послеледниковье по результатам ГИС-моделирования // Геоморфология, 2019, № 3, с. 83-90.

12. Шелехова Т. С., Субетто Д. А., Тихонова Ю.С., Потахин М.С. Диатомовые водоросли современных отложений озер Заонежья: палеоэкологические и палеоклиматические реконструкции // Общество. Среда. Развитие, 2015, № 2, с. 151-160.

13. Di Stefano C., Ferro V., Mirabile S. Comparison between grainsize analyses using laser diffraction and sedimentation methods // Biosystems Engineering, 2010, v. 106 , no 2, pp. 205-215.

14. Hang T., Gurbich V., Subetto D., Strakhovenko V., Potakhin M., Belkina N., Zobkov M. A local clay-varve chronology of Onega Ice Lake, NW Russia // Quaternary International, 2019, vol. 524, pp. 13-23.

15. Passega R., Byramjee R. Byramjee Grain-size image of clastic deposits // Sedimentology, 1969, vol.13, no 3-4, pp. 233-252. 


\title{
N.A. Myasnikova, M.S. Potakhin
}

16. Munsell soil color book (Munsell soil-color charts). USA, 2017.

17. Niemela J., Ekman I., Lukashov A. Quaternary deposits of Finland and northwestern part of Russian Federation and their resources. Scale 1:1 000 000. Espoo: Geological Survey of Finland, 1993.

18. Zobkov M., Potakhin M., Subetto D., Tarasov A. Reconstructing Lake Onego evolution during and after the Late Weichselian glaciation with special reference to water volume and area estimations // Journal of Paleolimnology, 2019, vol. 62, no 1, pp. 53-71.

Конфликт интересов: Авторы декларируют отсутствие явных и потенциальных конфликтов интересов, связанных с публикацией настоящей статьи.

Поступила в редакцию 28.09.2020

Принята к публикачии 02.03.2021

\section{Granulometric Composition of the Bottom Sediments in the Torosjarvi Lake (the White Sea Basin)}

\author{
N.A. Myasnikova $\bowtie$, M.S. Potakhin \\ Northern Water Problems Institute of the Karelian Research Centre RAS, Russian Federation \\ (50, Alexander Nevsky Ave., Petrozavodsk, 185000)
}

\begin{abstract}
Purpose: The bottom sediments in the small relict the Torosjarvi Lake were studied to track the evolution and more accurately outline the boundaries of the Onego periglacial Lake during the Late Glacial and Holocene times.

Methods. The granulometric composition of the bottom sediments was determined using the multifunctional laser diffraction particle size analyser LS 13320 (by Beckman Coulter, USA) at KarRC RAS Core Facility, and the output was then statistically treated.

Results: Two sediment cores were exposed, and their lithostratigraphic descriptions were produced in the field. The granulometric composition of sediments in the 4,40-5,40 m interval (core 2,5) was analyzed in the laboratory. The fractions sizes in this interval were found to range from fine sand to silty clay. The prevalent fraction was coarse silt. Based on granulometric analysis, the palaeo-hydrodynamic sedimentation environments are represented by turbidite deposits in three intervals $(4,68-4,69 ; 5,04-5,05$, and 5,14-5,15 m), while the other intervals $(4,71-4,81 \mathrm{~m}$ and $5,24-5,35 \mathrm{~m})$ fall in the zone deposited by low-velocity streams (homogenous suspension sediments).

Conclusions. The granulometric composition of bottom sediment cores from the Lake Torosjarvi revealed a prevalence of the coarse silt fraction $(0,01-0,05 \mathrm{~mm})$, which contributed $49,04 \%$ to $62,96 \%$. The sand fraction accounted for $21,36-38,62 \%$ and was mainly represented by fine sand. The clay fraction accounted for $0,44-1,61 \%$. A first analysis of changes in sedimentation in the Lake Torosjarvi based on the sediment core in the interval 4,4-5,4 m suggests there occurred five shifts in the dynamic water regimes in the course of the lake formation. The results of this study will be needed in further geoecological and palaeogeographical research.
\end{abstract}

Key words: bottom sediments, granulometric composition, fractions, Karelia.

Funding: This work was carried out as part of the research programme of the Northern Water Problems Institute of the Karelian Research Centre of the Russian Academy of Sciences.

For citation: Myasnikova N.A., Potakhin M. S. Granulometric Composition of the Bottom Sediments in the Torosjarvi Lake (the White Sea Basin). Vestnik Voronezskogo gosudarstvennogo universiteta. Seria: Geografia. Geoekologia, 2021, no. 1, pp. 45-56. (In Russ.) DOI: https://doi.org/10.17308/geo.2021.1/3255

(C) Myasnikova N. A., Potakhin M. S., 2021

$\triangle$ Nadezda A. Myasnikova, e-mail: nadezda_myasnikova@mail.ru 


\section{REFERENCES}

1. Demidov I.N. Chetvertichnye otlozheniya [Quaternary deposits]. Raznoobrazie bioty Karelii: usloviya formirovaniya, soobshchestva, vidy, 2003, pp. 19-27. (In Russ.)

2. Demidov I. N. O maksimal'noy stadii razvitiya Onezhskogo prilednikovogo ozera, izmenenii ego urovnya i glyatsioizostaticheskom podnyatii poberezhiy $\mathrm{v}$ pozdnelednikov'e [About the maximum stage of development of the Onega subglacial lake, a change in its level, and glacioisostatic uplift of the coasts in late glacial]. Geologiya i poleznye iskopaemye Karelii, 2006, v. 9, pp. 171-182. (In Russ.)

3. Zdobin D. Yu., Semenova L.K. O granulometricheskom analize glinistykh gruntov: lazernye i klassicheskie metody [About granulometric analysis of clay soils: laser and classical methods]. Geoekologiya, inzhenernaya geologiya, gidrogeologiya, geokriologiya, 2011, no. 6, pp. 560-567. (In Russ.)

4. Ezhova A. V. Praktikum po litologii: uchebnoe posobie [Workshop on lithology: study guide]. Tomsk: Izd-vo TPU, 2011. 147 p. (In Russ.)

5. Koval' S.A., Voytsekhovskiy G.V. Komp'yuternaya obrabotka rezul'tatov granulometricheskogo analiza $i$ ikh geneticheskaya interpretatsiya [Computer processing of the results of particle size analysis and their genetic interpretation]. Voronezh: Izd-vo VGU, 2001. 35 p. (In Russ.)

6. Lomtadze V.D. Inzhenernaya geologiya. Inzhenernaya petrologiya - 2-e izd., pererab. i dop [Engineering geology. Petrology Engineering]. Leningrad: Nedra, 1984. 511 p. (In Russ.)

7. Lukashov A.D. Geomorfologicheskie usloviya [Geomorphological conditions]. Raznoobrazie bioty Karelii: usloviya formirovaniya, soobshchestva, vol, 2003, pp. 13-19.

8. Potakhin M.S. Ryazantsev P.A., Gurbich V.A., Rodionov A.I., Subetto D.A. Izuchenie ozernykh otlozheniy yugo-zapadnogo Prionezh'ya [The study of lake sediments of the southwestern Prionecha]. Materialy nauchno-prakticheskoy konferentsii "Geoekologicheskie problemy i ustoychivoe razvitie Baltiyskogo regiona», Veliky Novgorod, 2017, pp. 55-61. (In Russ.)

9. Subetto D.A., Prytkova M. Ya. Donnye otlozheniya raznotipnykh vodoemov. Metody izucheniya [Bottom sediments of diverse reservoirs. Study methods]. Petrozavodsk: Karel'skiy nauchnyy tsentr RAN, 2016. 89 p. (In Russ.)
10. Subetto D.A., Potakhin M.S., Shelekhova T.S., Gurbich V.A. Paleogeografiya Onezhskogo ozera i ego vodosbora «PaleoOnego» [Paleogeography of Lake Onega and its watershed «PaleoOnego»]. Svidetel'stvo o gosudarstvennoy registratsii bazy dannykh № 2017620010. 2017. (In Russ.)

11. Subetto D.A., Potakhin M.S., Zobkov M.B., Tarasov A.Yu., Shelekhova T.S., Gurbich V.A. Razvitie Onezhskogo ozera v poslelednikov'e po rezul'tatam GIS-modelirovaniya [The development of Lake Onega in the postglacial period according to the results of GIS modeling]. Geomorfologiya, 2019, no. 3, pp. 83-90. (In Russ.)

12. Shelekhova T. S., Subetto D.A., Tikhonova Yu. S., Potakhin M.S. Diatomovye vodorosli sovremennykh otlozheniy ozer Zaonezh'ya: paleoekologicheskie i paleoklimaticheskie rekonstruktsii [Diatoms of modern sediments of Zaonezhye lakes: paleoecological and paleoclimatic reconstructions]. Obshchestvo. Sreda. Razvitie, 2015, no. 2, pp. 151-160. (In Russ.)

13. Di Stefano C., Ferro V., Mirabile S. Comparison between grainsize analyses using laser diffraction and sedimentation methods. Biosystems Engineering, 2010, vol. 106, no. 2, pp. 205-215.

14. Hang T., Gurbich V., Subetto D., Strakhovenko V., Potakhin M., Belkina N., Zobkov M. A local clay-varve chronology of Onega Ice Lake, NW Russia. Quaternary International, 2019, vol. 524, pp. 13-23.

15. Passega R., Byramjee R. Byramjee Grain-size image of clastic deposits. Sedimentology, 1969, vol.13, no. 3-4, pp. 233-252.

16. Munsell soil color book (Munsell soil-color charts). USA, 2017.

17. Niemela J., Ekman I., Lukashov A. Quaternary deposits of Finland and northwestern part of Russian Federation and their resources. Scale 1:1 000 000. Espoo: Geological Survey of Finland, 1993.

18. Zobkov M., Potakhin M., Subetto D., Tarasov A. Reconstructing Lake Onego evolution during and after the Late Weichselian glaciation with special reference to water volume and area estimations. Journal of Paleolimnology, 2019, vol. 62, no. 1, pp. 53-71.

Conflict of interests: The authors declare no information of obvious and potential conflicts of interest related to the publication of this article.

Received 28.09.2020

Accepted 02.03.2021 
Мясникова Надежда Александровна

кандидат географических наук, младший научный сотрудник Федерального исследовательского центра «Карельского научного центра Российской академии наук» Института водных проблем Севера КарНЦ РАН, г. Петрозаводск, Российская Федерация, ORCID: 00000002-3594-3805, e-mail: nadezda_myasnikova@mail.ru

Потахин Максим Сергеевич

кандидат географических наук, старший научный сотрудник Федерального исследовательского центра «Карельского научного центра Российской академии наук» Института водных проблем Севера КарНЦ РАН, г. Петрозаводск, Российская Федерация, ORCID: 00000002-2630-2176, e-mail: mpotakhin@mail.ru
Nadezda A. Myasnikova

Cand. Sci. (Geogr.), Junior Researcher of the Northern Water Problems Institute of the Karelian Research Centre of the Russian Academy of Sciences, Petrozavodsk, Russian Federation, ORCID: 0000-0002-3594-3805, e-mail: nadezda_myasnikova@mail.ru

\section{Maksim S. Potakhin}

Cand. Sci. (Geogr.), Senior Researcher of the Northern Water Problems Institute of the Karelian Research Centre of the Russian Academy of Sciences, Petrozavodsk, Russian Federation, ORCID: 0000-0002-2630-2176, e-mail: mpotakhin@mail.ru 